Original Research Paper

\title{
Marketing Management of Sustainable Development of Territories in Russia
}

\author{
${ }^{1}$ Irina Skorobogatykh, ${ }^{1}$ Daria Malova, ${ }^{1}$ Zhanna Musatova and ${ }^{2}$ Ekaterina Agalarova \\ ${ }^{I}$ Department of Marketing, Plekhanov Russian University of Economics, Moscow, Russia \\ ${ }^{2}$ Department of Economy of Firm and Business Technologies of Agro-Industrial Complex, \\ Stavropol Agrarian State University, Russia
}

Article history

Received: 06-10-2015

Revised: $22-10-2015$

Accepted: $28-1-2016$

Corresponding Author: Irina Skorobogatykh, Department of Marketing, Plekhanov Russian University of Economics, Moscow, Russia Email: russian-science@mail.ru

\begin{abstract}
Over recent years a characteristic feature of many countries has been the soaring importance of certain territories both at the national and international levels. A region is considered of primary level when the national economic system evolves. At the regional level, development and management of a territory is perceived from the perspective of target groups of its consumers-residents, businesses, investors, authorities and visitors. In order to attract tourists, investments and talents, territories compete globally. "Soft" factors, such as image and reputation, are becoming increasingly important in the process of deciding where to invest. Those factors are directions of strategic territory marketing. The concept of sustainable development originated in the process of searching for a new civilization model in the context of understanding the danger of using natural resources, in order to implement the strategy of satisfying the needs of the current population in the regions and to provide the same economic, social and ecological opportunities for future generations. In this article, the authors attempt to prove that sustainable development of the regions of the Russian Federation is feasible through using the concept of strategic marketing management.
\end{abstract}

Keywords: Marketing Places (Territories), Strategic Marketing Management, Sustainable Development of Regions, Typology of the Regions of Russia, Dynamic Modeling of Sustainable Development

\section{Introduction}

Current transformational processes pre-determine a methodological basis for Russia's sustainable development aimed at establishing a regulated socially-oriented market economy. Implementation of an integral national strategy of sustainable development requires the sustainable economic development of individual regions because a dual correlation, which exists between the level of regional economic development along with the social and economic priorities of the country, confirms the need for more detailed research on the issues surrounding sustainable economic development and determining the priority of addressing them at the regional level.

Economic and social transformations implemented in Russia objectively call for changes in methodology and the practice of territory management (Granberg et al., 2002; Granberg and Kistanov, 2003). In that context, the need for a clear understanding of a region as a social and economic system has become one of the key factors determining Russia's development. Those issues were discussed during the presentation of a draft of the research paper "Sustainable development: Designing a complex model" ordered and funded by the Ministry of Education and Science of the Russian Federation in 2012-13, with participation by this paper's authors from Plekhanov Russian University of Economics.

Being the largest country in the world, the Russian Federation must pay special attention to its regions. Regionalism policy in the context of globalization allows the development of effective measures to protect regional interests and use regional special features as advantages contributing to accelerated development. 
Integrating into the world economy, regions face increasingly tough competition for investments, skilled labor force and satisfying the ever-growing needs of the population for an acceptable standard of living.

From places where economic events take place, regions are transforming to sellers of goods and services, i.e., full-fledged subjects of economic relationships. Territorial resources are sold as a commodity, which has its price and utility. Therefore, this enables and calls for marketing of that commodity, i.e., marketing of a territory (Kotler et al., 1993; Pankrukhin, 2006). In this connection, the primary task is to create and develop a complex product, promote and sell goods and services produced in the territory. Regional management in Russia needs concrete practices of marketing analysis, territorial positioning and the development of marketing strategy as a key component of an integral strategy of a given territory's social and economic development. Based on these global and allRussian strategies, a region can be considered as a multifunctional and multifaceted system (Malova et al., 2012; Agalarova, 2014).

\section{Theoretical Background and Literature Review}

In the broadest sense of the word, "region" can be defined as a naturally historical space where people living within its boundaries carry out social, economic and public activities. According to the modern space structure of the Russian economy, regions are seen as active economic subjects that have their own economic resources and competitive advantages. According to Granberg and Kistanov (2003), "Russia's economy is not a single object but a multi-regional organism that operates based on vertical (center-regions) and horizontal (transregional) interactions and is a part of the world economic relationships system". In this context, it seems that marketing, as a managerial concept must contribute to understanding the complex management of social and economic development of regions.

At present, regional (territory) marketing belongs to the field of academic and practical interests and theoretical development both in Russia and overseas. A number of authors consider territory marketing as a kind of complex strategy for improving the competitiveness of cities, regions, districts, geographic zones, tourism destinations and entire states, aimed at conquering international markets and attracting target audiences (Kotler et al., 1993; Anholt, 2006; Pankrukhin, 2006). In addition, according to professor Kotler and co-authors, territory marketing is aimed at drawing extra material and non-material resources to a region through presenting its unique characteristics and advantages to the wider public (Kotler et al., 1995).
Over the period between 1993 and 2015, the world saw around 10 books on territory marketing, mostly by American and British authors. For the interests of this research, some of the key definitions concerning territorial marketing (regional marketing) were analyzed (Table 1).

Analysis of these and other definitions by international and Russian authors points out the lack of a fully-fledged academic, theoretical and methodological and practical approach to territory management in the context of ever-toughening competition for resources. There are no conceptual approaches to the development of a new territory management philosophy aimed at meeting the commercial and non-commercial needs of stakeholders, under comfortable and safe living and working conditions, within a territory. Only the works by D.V. Malova contain proof of understanding the complex (integral) nature of marketing of territories aimed at the sustainable development of a territory: "Marketing of territories is a holistic system of creating and promoting a region (territory) as a complex marketing product which has value for all contact audiences, with the purpose of providing sustainable development for the current and future generations" (Malova at al., 2013). Thus, marketing of a territory (regional marketing) is a type of marketing where an object of studying and managerial impact is presented by such a specific object as a territory. (The object of managerial impact and for marketing activities is territory or region). In the first part of the research the preliminary analysis of the titles of $\mathrm{Ph}$. D and Doctoral dissertations in the Russian state library electronic catalogue was done. Researchers organized the search of the dissertations' titles by different combinations of key words in the area of regional marketing, sustainable development of the regions, marketing places, territory marketing, marketing management of sustainable development. The first step- the search with key words regional marketing-gives us 1230 titles for the period of 1998-2014. On the second stage, the words' combination-sustainable development of regions of Russia-gives even more titles, because of the broad areanumber of titles was 1500 .

The key words-territory marketing (marketing places)- was the target for search on the next step of analysis. The quantity of titles reduced to 450 and the period decreased (2000-2014). The combination of the key words-sustainable development and marketing-gives us 350 titles of the dissertations (period of 2001-2014). Finally, the search was devoted to the titles by the key words-marketing management of the regional sustainable development-only 25 dissertations, presented in the last 10 years were found. This analysis defined the importance of the topic of sustainable development of the Russian regions, which should include the marketing 
management approach. This analysis shows the interest to the topic of regional sustainable development in the research of Russian Doctoral students and scientific schools. In addition, the growing interest to the topic of marketing management in relation of regional development was marked. However, the topic of marketing management approach for the sustainable development of regions in Russia is not yet quite developed (Fig. 1). This conclusion was the fundamental for further analysis in this study.

Through the application of territory marketing, a subject of management organizes object management in the competitive environment to achieve consumer preference that would reflect in the development of existing ones and well as the inflow of new human, financial and material resources. Implementation of territory marketing contributes to the territory's attractiveness as a place of residence, temporary visit and a place for conducting activities (Fedotov, 2004; Frolov, 2013). In addition, territorial marketing can contribute to improving regional social and economic policy and act as a set of tools for its implementation in the context of soaring importance of sustainable development (Malova et al., 2012; Agalarova, 2014).

Table 1. Analysis of the definition of marketing places

\begin{tabular}{lll}
\hline Authors & Definition of marketing places & Comments \\
\hline Kotler et al. (1993) & $\begin{array}{l}\text { Marketing places-marketing for the interests } \\
\text { of territories, its internal and external stakeholders } \\
\text { Anholt (2006) }\end{array}$ & $\begin{array}{l}\text { This definition is describing only how to adapt } \\
\text { the classical marketing theory to a given place } \\
\text { with the target market of a place. This process is } \\
\text { related with understanding that places are } \\
\text { competing for the people, resources and investments } \\
\text { Parinition is limited by branding which is } \\
\text { narrower than the complex marketing system } \\
\text { of regions }\end{array}$ \\
& $\begin{array}{l}\text { Marketing places (Territories)-marketing for the } \\
\text { interests of internal and external stakeholders of } \\
\text { a place. It can be viewed as marketing relationships } \\
\text { of stakeholders inside the place on different } \\
\text { products and services }\end{array}$ & $\begin{array}{l}\text { Definition includes the understanding of the } \\
\text { relationship approach for the marketing places }\end{array}$ \\
Arzhenovskyi (2011) & $\begin{array}{l}\text { Marketing of regions (Regional marketing)-A concept, } \\
\text { which requires the market orientation of regions, } \\
\text { including particular cities or rural areas, on the needs of } \\
\text { target customers interested in a territories' products or } \\
\text { services (for example, tourists, investors, industries, firms) }\end{array}$ & $\begin{array}{l}\text { Definition includes the list of target groups } \\
\text { of customers of regional products (not all } \\
\text { the stakeholders) }\end{array}$ \\
\hline
\end{tabular}

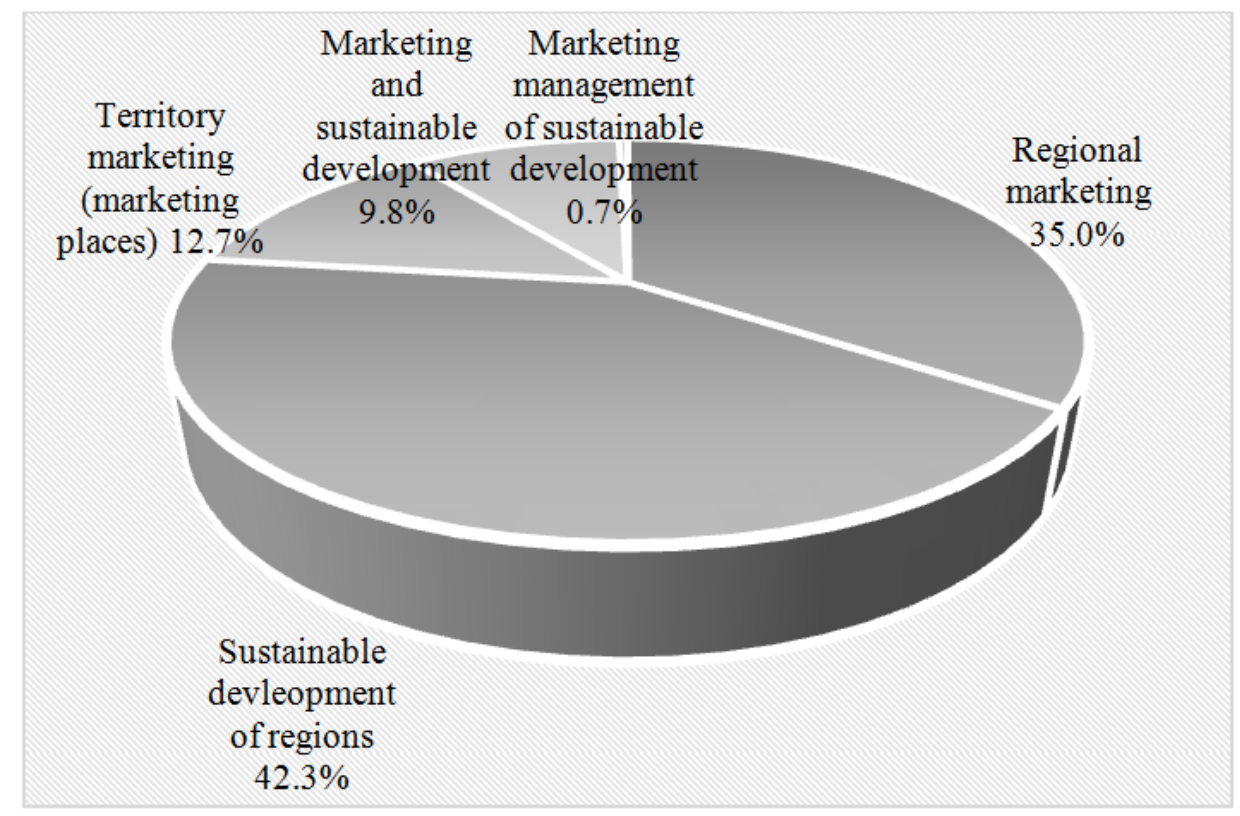

Fig. 1. Distribution of the key words of the area of study in the titles of Doctoral dissertations in Russia (Source: own research of dissertations titles in the Russian state library) 
Sustainable development is a harmonious (right, steady, balanced) development, a process of changes, when natural resources exploitation, investment channels, focus of scientific and technical development, personality development and institutional changes are consistent and strengthen the current and future potential for satisfying human needs and aspirations. According to the definition of the World Commission on Environment and Development, sustainable development is "development that meets the needs of the present without compromising the ability of future generations to meet their own needs", which is reflected in the UN report "Sustainable Development: From Brundtland to Rio 2012" prepared by the International Institute for Sustainable Development (Drexhage and Murphy, 2010). In our opinion, the sustainable development of a region consists of a balanced development of all spheres of public life based on the rational use of resources. The important aspect here is providing an acceptable standard of living for the region's population, which is the ultimate goal of territory marketing programs.

After determining the correlation between the sustainable development of regions (territories) and opportunities to apply marketing concepts for a complex regional management, one should determine the key directions of strategic territory marketing. In their first book "Marketing places", Philip Kotler and co-authors pointed out 4 directions of strategic marketing of territory: Marketing of image, marketing of attractiveness, marketing of infrastructure and marketing of population (personnel) (Kotler et al., 1993). In our opinion, the classification of strategic territory marketing should be expanded with the inclusion of marketing of image, marketing of sightseeing, event marketing, marketing of infrastructure and marketing of population. Each of these elements is described below.

Marketing of image implies creation and distribution of a universally recognized positive image of a given region. Compared to other directions this strategy is not particularly costly, although it requires certain expenses.

Marketing of sightseeing includes use of existing sites, such as nature, historical and cultural heritage and the creation of new sights (entertainment centers, free trade zones, malls and specific services- e.g., gambling clubs).

Event marketing is a set of measures aimed at promoting a territory through sporting events, festivals, conferences and congresses.

Marketing of infrastructure includes urban development, transport systems, telecommunications, social infrastructure, leisure activities, safety and ecology.
Marketing of population is a strategy oriented to a person being a holder of information about the territory. This is defined by the task of providing qualification and friendly motivation towards target audiences of the given territories.

Foreign countries and Russia have had quite successful practice implementing the above-mentioned directions of territory marketing (Table 2).

Thus, in order for the sustainable development of regions to make optimum use of resources in favor of existing and future generations of regional populations, the concept of marketing management should be implemented. Therefore, the marketing management of a region can be defined as a process of analyzing, planning and implementing marketing programs aimed at selling a complex regional product through mutually beneficial exchanges with stakeholders from the perspective of the region's sustainable development (Malova at al., 2012).

\section{Methodology}

From a marketing perspective, the sustainable development of social, economic and ecological elements (within the classic meaning of sustainability) is achieved through three Ps-people, planet and profit. In our opinion, this classic model should be expanded by up to 6 elements to include-economic, society, ecology, culture, politics, science and innovations (Fig. 2). Expansion of classical model of sustainable development is related to the expanded model of PESTEL analysis of macro-environmental marketing on strategic marketing management: Political, Economic, Social, Technological, Ecological and Legal factors. Therefore, we proposed the 6 elements, but Political and Legal can be added to each other, but at the same time due to the strategic goals for development of Russian regions the technological factors can include the factor of Innovations. This proposal made a link between the regional sustainable development and strategic marketing management of the region (territory), which will be explained later in this study.

In this case, politics should be considered as an institutional element, "leverages" to achieve target indicators (Kolomiichenko and Rokhchin, 2003; Bobylev and Makeenko, 2006; Bobylev et al., 2011).

Thus, the proposed model of sustainable development of region should include 5 elements, economics, society, culture, science and innovations, ecology.

The region is represented as deliberate and multipurpose system with heterogeneous internal and external objectives, independent sub-goals of the individual subsystems, the system of indicators for measuring purposes, diverse strategies to achieve them.

Table 3 shows the indicators, related with sustainable development of regions, proposed by researchers. 
Table 2. The examples of marketing projects classified by different approaches of the strategic marketing places

Examples of the implementation of different approaches of strategic marketing places

Marketing through the arts

Promotion through the medium of famous people

History and cultural heritage and cultural institutions

Development of sightseeing

Nature

Regional manufacturing and business

Trade

Events' organization

Natural Phenomena

Marketing of Image

Juliette's balcony in Verona (Italy)

221-b Baker street, London (address of Sherlock Holmes)

"Vicki, Christina, Barcelona" (movie)

The Russian Poet Sergey Esenin's House Museum in Konstantinovo

(Ryazan region of the Russian Fed.)

Excursions to Michail Bulgakov's places in Moscow (Russian Fed.)

Excursions to Drvengrad of Emir Kusturica (Serbia)

Tourist legends about artist Niko Pirosmani (Georgia)

The umbrella brand of Beatles in Liverpool (UK)

The umbrella brand of Antonio Gaudi in Barcelona (Spain)

Marketing of sightseeing

(Thematic marketing)

The umbrella brand "Golden ring?" (Tourists destinations in the center of

Russian Fed.)

The Bolshoy Theatre (Moscow, Russian Fed.)

The Louvre (France)

The State Hermitage Museum (Saint Petersburg, Russian Fed.)

Broadway (New York, USA)

Las Vegas casinos and shows (USA)

Disneyland, Disneyworld (USA)

Burj Khalifa. the tallest building in the world (Dubai, UAE)

The Dubai Mall (Dubai, UAE)

BMW museum in Munich (Germany)

The cultural and educational center "Ethnoworld" in Kaluga Region (Russian Fed.)

Lake Baikal (Russian Fed.)

Mount Everest (Tibet)

Grand Canyon (USA)

Caucasian Mineral Waters (Stavropol Region of Russian Fed.)

Silicon valley (USA)

Regional manufacturing of wines (Crimea, France, USA, etc.)

Free trade zones

Event marketing

Sochi-2014 Olympics Games

Universiada- 2013 (Kazan, Russian Fed.)

Eurovision (hosted by different countries)

Euro-2018 (Moscow, Russian Fed.)

The umbrella brand "White Nights in Saint Petersburg" (Russian Fed.)

Sakura blossom in Japan

Tours to Murmansk regions during the period of Aurora Polaris (Russian Fed.)

Marketing of Infrastructure

The launch of Russian lowcost airline "Dobrolet"

Rail and roads construction in Great Sochi (Russian Fed.)

Metro development in Nizhny Novgorod (Russian Fed.)

Marketing of the Population

Mass educational programs to learn English by the population in Sochi in advance of Sochi Olympic Games-2014 (Russian Fed.)

Mass educational programs to learn English by the population in Paging (China) in advance of Paging Olympic Games-2008

Volunteer movement at the Olympic Games 2014 in Sochi (Russian Fed.)

Source: Own research

Indicators are selected by years for the regions evaluated in terms of the sustainable development parameter. Then a comparative evaluation within each block of indicators (five out of six proposed) is carried out. Comparative evaluation for each indicator is done by using a method of relative differences based on the ratio between the current indicator value and its maximum and minimum values. This method is proposed by Abdikeev and co-authors in the book Cognitive business-analytics (Abdikeev et al., 2011). 
Table 3. Main indicators of the sustainable development of regions, classified by main approaches

\begin{tabular}{ll}
\hline Blocks of sustainable development of regions & Indicators \\
\hline Economics & Gross regional production per capita (GRP per Capita) \\
& The economically active population, in \% of total population \\
& The average monthly nominal wage per employee \\
& The number of employees engaged in research and development for \\
Science and innovations & every 10 thousand people employed in the economy (people) \\
& Share of innovative production \\
& Current domestic expenditure on R\&D as a \% of gross regional production \\
Society & The unemployment rate (as a \% of the working population) \\
& Coverage of pre-school educational institutions, children of the appropriate age, \% \\
& Population per physician (people) \\
& Total reported crimes per 100 000 population \\
Ecology & Protected areas (reserves and national parks) as a \% of total area \\
Culture & Number of visits to theaters per capita \\
& Number of visits to museums per capita \\
\hline
\end{tabular}

Source: Own research

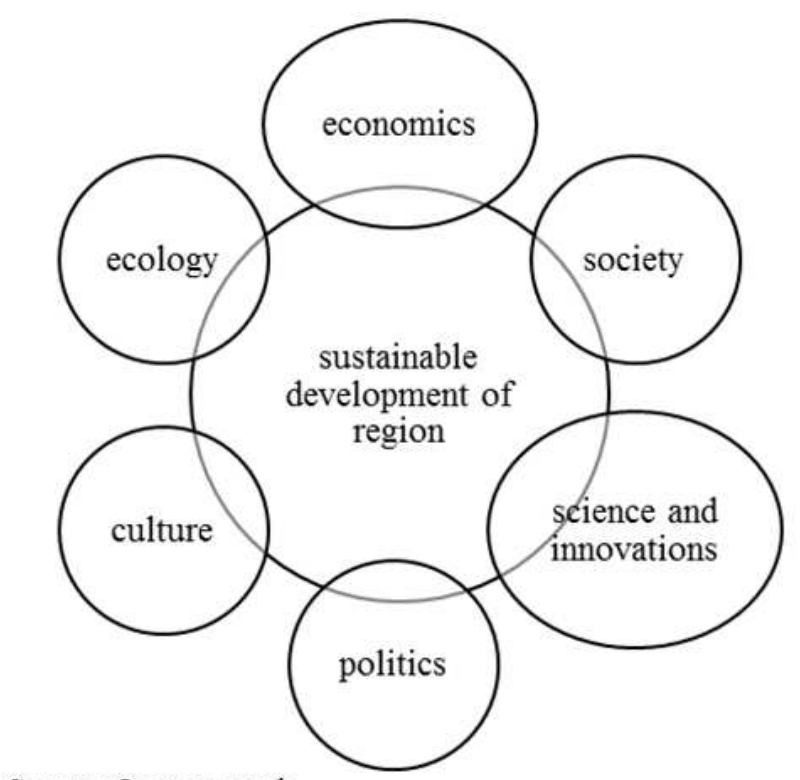

Source: Own research

Fig. 2. The system of sustainable development of region

Evaluation is defined as:

$$
K_{i}=\frac{X_{i}-\min \left(X_{i}\right)}{\max \left(X_{i}\right)-\min \left(X_{i}\right)}
$$

Where:

$K_{i}$

$X_{i} \quad=$ Value of the index $\mathrm{i}$ in the region

$\operatorname{Max}\left(x_{i}\right), \min \left(x_{i}\right)=$ Minimum and maximum index values $\mathrm{xi}$, as which may be selected real maximum and minimum threshold values or conditional. The formulas 1-4 for calculations of indicators were proposed by researchers and based on the methodology of business analytics

Then a comprehensive indicator of sustainable development for each block is calculated:

$$
I_{j}=\sqrt{\frac{\sum_{i=1}^{n} K_{1}}{n}}
$$

where, $I_{j}$, is a comprehensive indicator of stability parameters for each block.

Then the Integral indicator of sustainable development is calculated. This indicator is the sum of the coefficients of the blocks with a value, calculated as follows: 


$$
I=K_{i} \times I_{i}+R_{2} \times I_{2}+\ldots K_{n} \times I_{n}
$$

where, $K_{1}, K_{2}, K_{3} \ldots K_{n}$, coefficients reflecting the importance of each of the components taken into account (specific area) and $I_{n}$ are complex indices for each block of indicators.

In addition, for the calculation of the integral index, one can apply geometric mean value.

In this case, the values of the blocks will be erected in a degree that reflects the significance of the coefficient block. Then, integral Stability Index can be calculated using the following formula:

$$
I_{\text {sust }}=\sqrt[5]{K_{\text {economic }}^{7}+K_{\text {social }}^{7}+K_{\text {scientific }}^{7}+K_{\text {ecol }}^{7}+K_{\text {cult }}^{7}}
$$

Where:

$\begin{array}{ll}I_{\text {econ }} & =\text { Economic sustainability } \\ I_{\text {social }} & =\text { Social sustainability } \\ I_{\text {scientific }} & =\text { Scientific sustainability } \\ I_{\text {ecol }} & =\text { Ecological sustainability } \\ I_{\text {cult }} & =\text { Cultural sustainability } \\ K_{n} & =\text { Boost factors blocks }\end{array}$

As the index must reflect sustainable development and all components have equal significance, the significance coefficients are set equal to zero. This method of building a uniform integral index allows for the calculation of values for all components involved.

After calculating an integral stability index for the region in question, integral estimation of the region's sustainability is interpreted. Threshold values of sustainable development vary from 0 to 1 . There are five levels of regional sustainability (Table 4). Indicators of sustainable development estimation may vary. Depending on the situation analysis of the territory and new internal and external factors influencing its development in dynamics, indicators can be specified and expanded at the same time (Atkisson, 2012).

A single integral index provides a more detailed and unequivocal perception of the regions' sustainable development and allows conducting a general rating of Russia’s regions (Gokhberg, 2014).

\section{Results}

A region (titled as krai, oblast), as a part of the administrative division of the Russian Federation, is a purposeful and multipurpose system with non-uniform internal and external purposes, autonomous subpurposes, a system of purpose-estimating indices, holds various strategies for purpose achievement, etc. The general purpose of the system can be presented as a number of weakly formalized related sub-purposes. When choosing one or another development path, one has to make a coordinated decision, which would allow compromises to be reached between stakeholders' interests, as well as between goals of the whole country, region and individual enterprises and business units. The system in question has a complex internal structure due to the following reasons:

- Blurred regional borders

- Non-conformed goals of regional stakeholders

- Influence of all spheres of life on the region's sustainability

- Legislation defects and lack of a single regulation law in a number of fields

- Multitude of implicit relationships

- Imperfect and incomplete statistical data

Due to existing imperfections in social, economic, ecological, cultural, scientific and political system of the region, it is proposed that cognitive modeling methodology is used based on designing a subjective model of the situation. This methodology is applied to support decision-making in weakly structured dynamic situations (Abdikeev et al., 2011). A subjective model of sustainable development of regions of the Russian Federation is designed by expert method and is presented as an oriented signed graph (cognitive map), where peaks are situation factors and weighted curves are cause-and-effect relations, whose weight reflects the power of impact of given situational factors.

Figure 3 shows a dynamic model of a region's sustainable development built as a part of this research and applied in Power Sim Studio.

The model includes the following levels:

- $\quad 1^{\text {st }}$ level. Coefficients of implementation of strategic marketing directions

- $\quad 2^{\text {nd }}$ level. Indicators of sustainable development of a region discussed in the Methodology section

- $\quad 3^{\text {rd }}$ level. Synthetic indices according to 5 blocks of region's sustainable development (economics, society, culture, ecology, science and innovations)

- $4^{\text {th }}$ level. Integral sustainability index

- $5^{\text {th }}$ level. Significance coefficients for block indicators

The model is referred to as dynamic, because the sustainability index can vary as individual coefficients change. In addition, coefficient calculation by blocks allows one to make effective managerial decisions in the five key directions of strategic marketing. Significant coefficients for block indexes are determined by specialization and factors typical for the region (for example, tourism, traditionally industrial or agricultural region, conservation areas, access to sea, scientific or educational institutions that increase the amount of labor force, etc.). All significance coefficients are set equal to unity. 
Table 4. Interpretation of the integral indicator of the sustainable development of a region

\begin{tabular}{lll}
\hline Sustainability level & Interval & Evaluation of sustainable development \\
\hline 1 & $0.8<I_{\text {sust }}<1$ & Development of region is sustainable \\
2 & $0.6<I_{\text {sust }}<0.8$ & Development of region is nearly sustainable \\
3 & $0.4<I_{\text {sust }}<0.6$ & Development of region with elements of instability \\
4 & $0.2<I_{\text {sust }}<0.4$ & Instability of the regional development \\
5 & $0<I_{\text {sust }}<0.2$ & Crises condition (turbulence) \\
\hline
\end{tabular}

Source: Own research

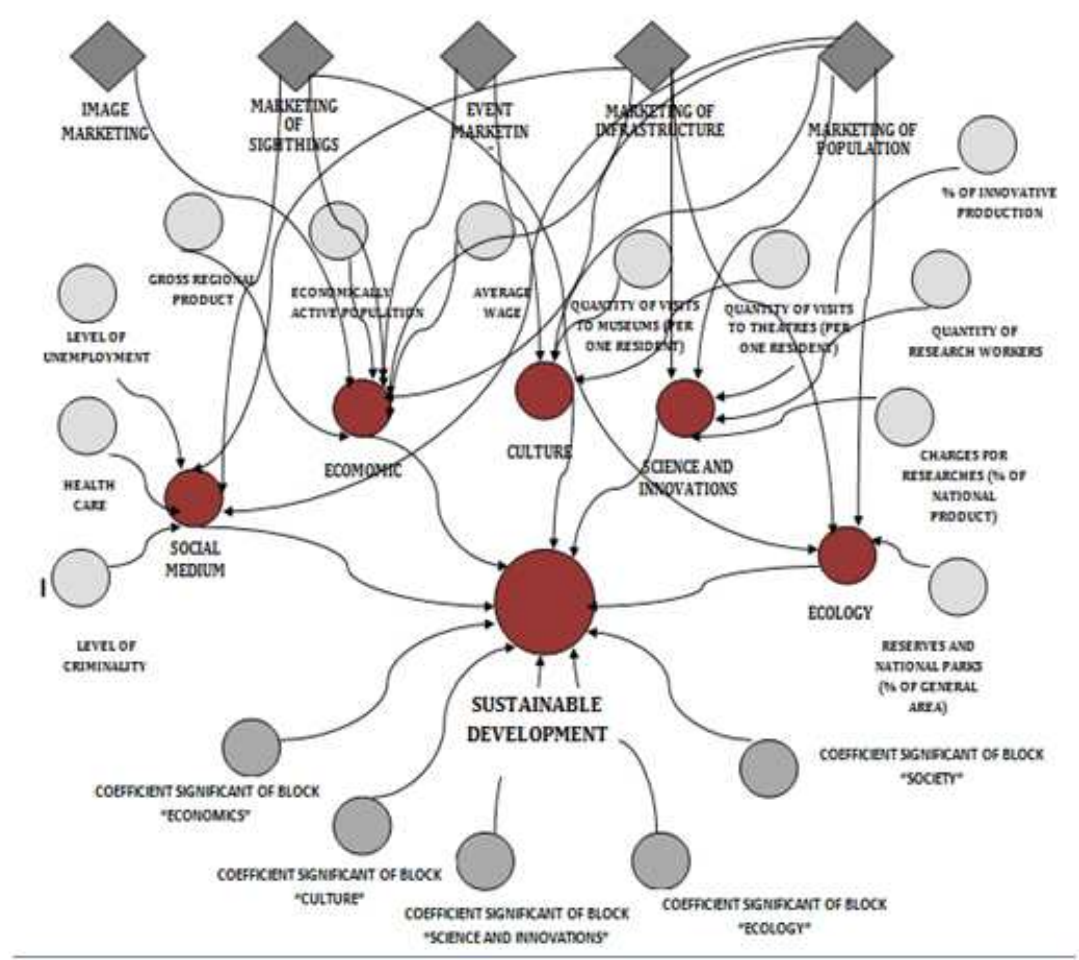

Source: Own research

Fig. 3. Dynamic model of sustainable development of a region

\section{Analysis}

The fact that the marketing management of regions, with similar specializations but different levels of development will be mostly the same calls for the need to present the typology of the regions in question based on their areas of specialization. During our research, three regions were analyzed-traditionally industrial region (Perm Krai), tourism region (Crimean Federal District) and agricultural region (Stavropol Krai). The above-mentioned main statistical indicators for the regions' development have been taken from recommended official statistical sources (Bobylev and Makeenko, 2006; Bobylev et al., 2011; Musatova, 2014).

The Crimean Federal District was established on March 21, 2014 by the Presidential Decree. CFD is not just a new subject of the Russian Federation, but a largescale political project, the development of which will be watched by the whole world. For that reason, the development strategy for the Crimean Peninsula must include powerful marketing tools for the region's positioning. CFD may become a promising new brand for tourism and industrial and agricultural development.

According to the statements made by representatives of the Russian executive authorities, in the next two or three years alone Crimea's infrastructure will be funded with about 250 bln rubles in the form of government and quasi-government investments, which equals the aggregated amount of investments into the region over the last five years.

Compared to other subjects of Russia, the Republic of Crimea has extremely low indicators of economic development- $82^{\text {nd }}$ by GRP per capita, setting it in the last place by per capita income (FLRF, 2014).

Tourism has the largest investment potential in the Crimean Federal District. The relevant programs must address two issues-attracting large hotel operators to Crimea and facilitating a stable environment for legal 
small businesses. At the same time, the region and the country's executives should build a precise marketing strategy for the region's positioning, which would allow the region to differentiate by specializing in tourism, recreation and treatment from the coastal regions of Krasnodar Krai and North Caucasus in order to develop a communications policy and promotion.

As of 2015, the region's sustainability is extremely low (based on the above-mentioned indicators by five blocks). This fact is defined by the following risks:

- Low income per capita

- High crime rate

- Critical state of science (severe lack of personnel involved in research and developments, the amount of personnel is decreasing; lack of science funding) resulting in economic risks

- Crimea's GRP is more than 3.7 (!) times lower than the national average

At the same time, culture indicators are average compared to other regions (Table 5).

The second subject studied was Perm Krai, which is a part of the Volga Federal Okrug and can be classified as a traditionally industrial region. Being one of the economically developed regions of Russia, Perm Krai occupies $12^{\text {th }}$ place by GRP (897.6 bln rubles). The region's economy is dominated by the highly developed industrial complex, which is based, primarily, on a raw-material economic model. One can say that effectiveness of raw-material industries implies a relatively high level of risk, because prices for raw materials are set outside the regional economy and are determined by the international economic environment. A long-term social and economic development program for Perm Krai must focus on industries, which may not have a large share in GRP yet, but show growth potential (communications, IT, tourism and culture). Over recent years, the share of industry in GRP has been decreased and replaced by the services sector. The key positive features of Perm Krai which can be used for region positioning are the following: The practice of marketing of territories in Russia (besides capital cities), scientific and innovation centers with developed scientific structure, a traditionally industrial region with emerging innovation clusters and the marketing project "Perm: Cultural capital of Russia" implemented by using all strategic marketing blocks.

Table 5. Comparative analysis of the statistical indicators of three regions of Russian Federation on 5 blocks of sustainable development

\begin{tabular}{|c|c|c|c|c|c|}
\hline Blocks & Indicators & $\begin{array}{l}\text { Russian } \\
\text { Federation, total }\end{array}$ & $\begin{array}{l}\text { Perm } \\
\text { region }\end{array}$ & $\begin{array}{l}\text { Crimean } \\
\text { federal district }\end{array}$ & $\begin{array}{l}\text { Stavropol } \\
\text { region }\end{array}$ \\
\hline \multirow[t]{3}{*}{ Economics } & GRP per capita, 2012, rubles & 348598.9 & 340933.200 & 94781.5000 & 154529.600 \\
\hline & $\begin{array}{l}\text { Economically active population, } \\
\text { in } \% \text { of total population }\end{array}$ & 52.6 & 50.700 & 46.2000 & 49.400 \\
\hline & $\begin{array}{l}\text { The average monthly } \\
\text { nominal wage per employee } \\
\text { (data as of May 2014), rubles }\end{array}$ & 32272.0 & 29861.500 & 11512.0000 & 20656.000 \\
\hline \multirow[t]{3}{*}{$\begin{array}{l}\text { Science and } \\
\text { innovations }\end{array}$} & $\begin{array}{l}\text { The number of employees } \\
\text { engaged in R\&D for every } \\
10 \text { thousand people employed } \\
\text { in the economy (persons), } 2013\end{array}$ & 101.5 & 80.600 & 12.0000 & 16.700 \\
\hline & Share of innovative products in 2013 & $8(9.2)$ & 16.700 & 3.3000 & 9.700 \\
\hline & $\begin{array}{l}\text { Current domestic expenditure on } \\
\text { R\&D as a \% of gross regional } \\
\text { production in } 2012\end{array}$ & 2 & 1.200 & 0.0040 & 0.003 \\
\hline \multirow[t]{4}{*}{ Society } & $\begin{array}{l}\text { Unemployment rate (as a } \% \text { of the } \\
\text { working population) }\end{array}$ & 5.5000 & 6.500 & 1.3000 & 5.600 \\
\hline & $\begin{array}{l}\text { Coverage of pre-school educational } \\
\text { institutions, children of the appropriate } \\
\text { age, } \%\end{array}$ & 59.4000 & 66.040 & $53 \%$ & 58.100 \\
\hline & Population per physician (people) & 203.8000 & 200.100 & 214.6000 & 236.800 \\
\hline & $\begin{array}{l}\text { Registered crimes per } 100,000 \\
\text { people, }(2013)\end{array}$ & 1537.0000 & 2150.000 & 1760.4000 & 1212.000 \\
\hline Ecology & $\begin{array}{l}\text { Protected areas (reserves and national } \\
\text { parks) as a } \% \text { of the total area }\end{array}$ & 0.0253 & 0.017 & 0.2877 & 1.500 \\
\hline \multirow[t]{2}{*}{ Culture } & Number of visits to theaters per capita & 0.2450 & 0.300 & 0.1800 & 0.090 \\
\hline & $\begin{array}{l}\text { Annual attendance of museums } \\
\text { per inhabitant }\end{array}$ & 0.7 .00 & 0.360 & 1.3000 & 0.300 \\
\hline
\end{tabular}

Source: The statistical data and indicators on the types of economic activities; The statistical indicators and data of the economic development of the Republic of Crimea (SDIPR, 2015; SDISR, 2015; FSASRF, 2015; CRTDFSSSRF, 2015; Own research) 
The third region of the Russian Federation used for comparison is Stavropol Krai with a traditionally agricultural economic focus. Agriculture is the backbone of the region's economy. Based on the agricultural potential of Stavropol Krai, it is economically reasonable to maintain the key role played by agriculture in the region's economy. At the same time, the single-industry economy of rural areas rated as low, because economically and socially unfair public estimation of agricultural labor fails to provide an acceptable level of income for rural populations. The environmental and climatic conditions of Stavropol Krai encourage the cultivation of almost all types of agricultural crops, including grapes and wine (Ledneva and Rybasova, 2014). Stavropol Krai is one of Russia's leading wheat producers (rated $3^{\text {rd }}$ after Krasnodar Krai and Rostov Oblast). Due to its geographical position and proximity to the North Caucasus, Stavropol Krai distinguishes itself among other regions by the cultural variety of its population. Within the territory of the region lie the famous Caucasian Mineral Water climatic resorts, which imply tourism potential and attractiveness for both tourists and the local people. To improve the region's positioning as an agricultural and tourism center, the region's authorities should address the social problems of the rural population, secure employment, maintain an acceptable level of income and the cultural uniqueness of the rural population and develop marketing programs aimed at the promotion of its resorts. This kind of positioning should be implemented by preventing the rural population from leaving the countryside. This can be achieved, in particular, by supporting novice farmers and family livestock farms as well as maintaining existing farming community industry. In 2014, these measures allowed for the creation 52 new businesses and more than 200 workplaces. Over 2011-2014, 188 farmers started or improved their business, including 147 novice farmers and 41 directors of family livestock farms (Agalarova, 2014). It is recommended to further promote these measures, along with the development of the tourism monobrand-Caucasian Mineral Waters.

Table 5 shows comparative statistical indicators from the key blocks of the sustainable development model for the three regions of the Russian Federation.

\section{Conclusion}

The proposed methodology gives analyst possibility to develop tables through searching the statistical data on the main indicators, which are grouped into 5 blocks of sustainable development and this approach can be the bases for the further decisions how to improve position of the region with use of the marketing management approach.
It should be noted that further research on estimating sustainable development and designing strategic marketing programs for Russian regional development should focus on studying the impact of a successful marketing strategy on the effectiveness and profitability of marketing solutions aimed at improving the sustainable development of a region (Musatova, 2014).

The developed methods, models, algorithms and guidance provide a region's authorities with the opportunity to influence the sustainable development of a region and improve its competitiveness.

\section{Acknowledgement}

The authors would like to express their gratitude to the management of Plekhanov Russian University of economics (especially vice rector for education and informatization professor Olga A. Grishina) for their support and patience concerning the project to construct the model of sustainable development, which we adapted for the regional development. We would also like to give our special thanks to the department of marketing at Plekhanov RUE, the first scientific marketing school in Russia, for the opportunity to study modern marketing issues and new concepts.

The Department of marketing, Plekhanov Russian University of Economics funded this article.

\section{Author's Contributions}

Daria Malova: Designed the research plan, participated in the results analysis, contributed to the reviewing of the article critically.

Irina Skorobogatykh: Organized the study, data collection of the study sample, analysis and writing of the manuscript.

Ekaterina Agalarova and Zhanna Musatova: Contributed in development of the conceptual framework, results analysis, drafting of the article.

\section{Ethics}

The authors have no conflicts of interest in the development of the research and publication of this article.

\section{References}

Abdikeev, N.M., A.N. Averkin, L.P. Diakonova, N.B. Zavialova and E.I. Kistrina et al., 2011. Cognitive Business-Analytics. 1st Edn., Infra-M, Moscow, pp: 511.

Agalarova, E.G., 2014. Specifics of marketing management of social and economic development of rural areas. Scientific Proceedings of the Free Economic Society of Russia, (ESR' 14), pp: 56-62. 
Anholt, S., 2006. Competitive Identity: The new Brand Management for Nations, Cities and Regions. 1st Edn., Palgrave Macmillan, New York, ISBN-10: 0230627722, pp: 134.

Arzhenovskyi, I.V., 2011. Marketing of Regions. 1st Edn., Unity-Dana, Moscow, pp: 135.

Atkisson, A., 2012. How Sustainable Development Can Change the World? 1st Edn., BiNom, Knowledge Laboratory, Moscow, pp: 456.

Bobylev, S.N. and P.A. Makeenko, 2006. Indicators of Sustainable Development of Russia. 1st Edn., Publishing House of Higher School of Economics, Moscow, pp: 221.

Bobylev, S.N., N.V. Zubarevich, S.V. Solovieva and Y.S. Vlasov, 2011. Sustainable Development: Methodology and Methods of Measurement. 1st Edn., Economica, Moscow, pp: 358.

Drexhage, J. and D. Murphy, 2010. Sustainable development: From Brundtland to Rio 2012. United Nations Headquarters, New York.

FLRF, 2014. On the development of the Crimean federal district and the Free Economic Zone in the Territories of the Republic of Crimea and the Federal City of Sevastopol. Official website of the Ministry of Economic Development of Crimea, Federal Law of the Russian Federation No. 377-FZ.

Fedotov, A.N., 2004. Marketing Analysis of the Regional Development. 1st Edn., Publishing house of Baikal State University of Economics and Law, Irkutsk, pp: 157.

Frolov, D.P., 2013. Marketing Paradigm of the Regional Development. 1st Edn., Volgograd State University Press, Volgograd, pp: 147.

Gokhberg, L.M., 2014. Rating of Innovation Development of Regions of Russian Federation. 2nd Edn., Publishing House of Higher School of Economics, Moscow, pp: 69.

Granberg, A.G. and V.V. Kistanov, 2003. State-Based and Territorial System of Russian Federation. 1st Edn., Economica, Moscow.
Granberg, A.G., V.I. Danilov-Danilian, M.M. Tsikanov and E.C. Shopkhoev, 2002. Strategy and Sustainable Development Problems of Russia in 21 Century. 1st Edn., Economica, Moscow, pp: 402.

Kolomiichenko, O.V. and V.E. Rokhchin, 2003. Strategic Planning of the Regions' Development: Methodology, Organization. 1st Edn., Nauka, Saint Petersburg, pp: 203.

Kotler, P., I. Rein and D. Haider, 1993. Marketing Places: Attracting Investment, Industry and Tourism to Cities, States and Nations. 1st Edn., The Free Press, New York, ISBN-10: 0029175968, pp: 388.

Ledneva, Y.A. and Y.V. Rybasova, 2014. Grape and wine production of Stavropol region: The analysis of the status and trends of development. APK Stavropolia Bull., 3: 263-268.

Malova, D.V., I.I. Skorobogatykh and O.V. Saginova, 2012. The concept of sustainable marketing for the cluster initiative development. Barnaul: Altai Sci. Bull., 3: 13-17.

Musatova, Z.B., 2014. The concepts of the economic effectiveness of marketing decisions. Initiatives of 21 st Century.

Pankrukhin, A.P., 2006. Marketing of Territories. 2nd Edn., Piter, Saint Petersburg, pp: 410.

SDIPR, 2015. The statistical data and indicators of Perm Region.

SDISR, 2015. The statistical data and indicators of Stavropol Region.

FSASRF, 2015. The statistical data and indicators on the types of economic activities. Official website of the Federal State Agency for Statistics of Russian Federation.

CRTDFSSSRF, 2015. The statistical indicators and data of the economic development of the Republic of Crimea. Official website of the Crimea Republic Territorial department of the Federal State Statistics Service of Russian Federation (CrimeaStat). 